\title{
How do light and temperature affect laboratory investigations on serum bilirubin?
}

\section{Wickrama Rathnage Sureka Damayanthi, Atthanayaka Mudiyanselage Srimali Bandara, Athapaththu Mudiyanselage Buddhika Priyadarshani}

Department of Allied Health Sciences, Faculty of Medical Sciences, University of Sri Jayewardenepura, Gangodawila, Nugegoda, Sri Lanka.

\section{Email address:}

Corresponding author. Dr. A.M.B. Priyadarshani, Department of Allied Health Sciences, Faculty of Medical Sciences, University of Sri Jayewardenepura, Gangodawila, Nugegoda, Sri Lanka.

E mail: priyadarshani@sjp.ac.lk

\section{To cite this article:}

Wickrama Rathnage Sureka Damayanthi, Atthanayaka Mudiyanselage Srimali Bandara, Athapaththu Mudiyanselage Buddhika Priyadarshani. How do light and temperature affect laboratory investigations on serum bilirubin? Vol. 1, No. 2, 2018, pp. 4-13. DOI 10.26739/2523-1243

\section{doi ${ }^{\circ}$ http://dx.doi.org/10.26739/2523-1243/-2018-1-2-1}

\begin{abstract}
Bilirubin is important in disease diagnosis and it is considered as a photosensitive molecule. Therefore, precautions are important while analyzing samples to be measured bilirubin in the laboratory to avoid under-estimations. Hence, this study was designed to investigate the effect of temperature, sun-light and artificial light on the stability of serum bilirubin. Whole blood was collected from 34 apparently healthy subjects and serum was separated. To determine the effect of temperature serum was exposed to $-4^{\circ} \mathrm{C}$ and $33^{\circ} \mathrm{C}$ for $2 \mathrm{~h}$ and $24 \mathrm{~h}$. To investigate the effect of light the serum specimens were exposed to sun-light for $6 \mathrm{~h}$ and two CFL bulbs, $15 \mathrm{~W}$ each for $24 \mathrm{~h}$. Bilirubin concentrations were measured by dimethylsulfoxide method using automated Mindray BF 300 analyzer. The differences between base-line bilirubin value and other subsequent measurements were analyzed by post-hoc Dunnets test. There were significant reduction in all the bilirubin fractions in the samples exposed to sun-light for $6 \mathrm{~h}$ and only total and indirect bilirubin fractions significantly had been reduced in the samples exposed to artificial light. The same effect was observed in the normobilirubinaemic samples exposed to $33^{\circ} \mathrm{C}$ for $24 \mathrm{~h}$ but in hyperbilirubinaemic samples all the bilirubin fractions had been reduce significantly. There was no significant reduction of bilirubin in samples stored at $-4^{\circ} \mathrm{C}$ for $2 \mathrm{~h}$ and $24 \mathrm{~h}$ and at $33^{\circ} \mathrm{C}$ for $2 \mathrm{~h}$. Therefore, serum samples to be measured bilirubin can be stored at $4^{\circ} \mathrm{C}$ up to $24 \mathrm{~h}$ and $33^{\circ} \mathrm{C}$ up to $2 \mathrm{~h}$ with light protection, without significant changes in bilirubin concentrations.
\end{abstract}

Keywords: Direct bilirubin; Indirect bilirubin; Total bilirubin; Light, Temperature. 


\section{Introduction}

Bilirubin is a tetrapyrrole and is formed by heme catabolism. Hence, bilirubin is not fully soluble in plasma, it binds with albumin to transport in to the liver. Inside the hepatocyte two glucuronic acid molecules are reacted with bilirubin to increase the solubility of bilirubin. The enzyme microsomal bilirubin glucuronyltransferase catalyzes this reaction. The process is known as "bilirubin conjugation" (Harvey and Ferrier, 2011; Murray et al., 2003).

In the serum, bilirubin is measured as direct bilirubin and total bilirubin. In the clinical practice conjugated bilirubin is referred as "direct bilirubin" whereas unconjugated bilirubin is known as "indirect bilirubin". Direct bilirubin is the fraction which moves freely in the circulation while indirect fraction is bound to serum albumin (Harvey and Ferrier, 2011; Murray et al., 2003). Jaundice is caused by the elevated bilirubin levels in blood. Jaundiced patients can be diagnosed by the yellowish color of the skin, sclera and nail beds due to the deposition of bilirubin. Jaundice can be pre-hepatic, hepatic or post-hepatic (Harvey and Ferrier, 2011; Murray et al., 2003). Hyperbilirubinaemia in new born is more critical than adult because when unconjugated bilirubin fraction reaches harmful level, it can diffuse into the basal ganglia by passing the blood brain barrier (Westwood, 1991).

Serum bilirubin fraction determination is one of the most important laboratory investigations in the clinical practice in diagnosis of diseases. It is used as an indication of the severity of hepatic dysfunction. Unconjugated hyperbilirubinaemia is commonly caused as a result of increased bilirubin production via haemolysis and dyserythropoiesis, decreased hepatic clearance, defective bilirubin conjugation or multi-factorial etiologies. Conjugated hyperbilirubinaemia can be seen in individuals with hepatitis, liver infiltration, biliary obstruction with inherited disorders, primary biliary cirrhosis or with other causes such as sepsis, shock and hemochromatosis (Harvey and Ferrier, 2011; Murray et al., 2003). As well, serum bilirubin fraction determination is used to diagnose the type of jaundice and related clinical conditions. Neonatal bilirubin determination is also extremely important in routine neonatal diagnostic screening tests (Westwood, 1991).

Quantitative determination of serum bilirubin fractions ie., direct, indirect and total bilirubin is important in the correct diagnosis of diseases. It has been reported that there is a tendency to decrease the level of bilirubin in the serum/plasma due to factors such as exposure to various light intensities, temperatures and exposing time period to each factor and inappropriate sample handling. Therefore, precautions should be taken to protect the clinical specimens to be measured bilirubin from the light and temperatures to prevent the underestimations. If there is any underestimation during analysis it can affect the patient badly due to incorrect diagnosis of the exact disease condition. Therefore, the sample should be immediately analyzed and necessary precautions should be taken while analyzing the clinical specimens for bilirubin determination.

However, it has been reported that possible delay in the analyzing of serum/ plasma bilirubin due to heavy workload or delay in samples transportation to 
Wickrama Rathnage Sureka Damayanthi, Atthanayaka Mudiyanselage Srimali Bandara, Athapaththu Mudiyanselage Buddhika Priyadarshani. How do light and temperature affect laboratory investigations on serum bilirubin?

laboratories from wards/collection centers as a common problem in most of the hospitals/laboratory setups in developing countries (Saththasivam et al., 2010). Therefore, it is important to investigate that what would happen to the concentration of bilirubin fractions ie., direct, indirect and total bilirubin after exposing to temperature and light while performing laboratory analysis or if there is any delay in analyzing. Hence, the objective of present study was to determine the effect of light and temperature on stability of serum bilirubin.

\section{Materials and Methods}

The study was conducted after obtaining ethical approval from the Ethical Review Committee, Faculty of Medical Sciences, University of Sri Jayewardenepura, Sri Lanka.

\section{Study population}

Study population included healthy individuals within 18-35 age group. The subjects were recruited to the study, by providing a self-administered questionnaire. By observing the answered questionnaires, healthy individuals were selected to the study by considering inclusion and exclusion criteria. Exclusion criteria included individuals who were clinically diagnosed as suffering from any kind of disease condition and pregnant mothers.

\section{Sample size calculation}

Sample size was calculated according to the Paired sample $T$ test calculation criteria. Minitab version 17 software calculator was used for the calculation. The calculated sample size was 34 .

\section{Sample processing}

\section{Collection of blood samples}

The $5 \mathrm{~mL}$ of whole blood was drawn from the median cubital vein by veni puncture. All the blood samples were collected in to labeled plane tubes. All the collected blood samples were protected from light and heat.

\section{Separation of serum}

All the collected blood samples were kept for 10 min at room temperature with light protection. After $10 \mathrm{~min}$, all the samples were checked for clot formation. As some of the samples were not completely clotted after $10 \mathrm{~min}$ they were left for another $5 \mathrm{~min}$ at room temperature. Then the blood clots of all the plane tubes were detached from the bottom of the tube by gently tapping the bottom of the tubes. Then all the samples were centrifuged at $3000 \mathrm{rpm}$ for $10 \mathrm{~min}$. At the end of centrifugation, samples were examined for haemolysis.

\section{Aliquoting of serum samples}

After serum separation, each sample was aliquoted into seven, each aliquot containing $250 \mu \mathrm{L}$ of serum. The aliquots were put in to the Khan tubes and numbered from Aliquot No: 1-7. All the Khan tubes were covered with black papers to protect the serum samples from light. Aliquot No: 1 from all the serum samples $(n=34)$ was used to determine the base-line value of direct, indirect and total bilirubin.

\section{Determination of effect of temperature} on serum bilirubin concentration

To determine the effect of temperature, each serum aliquot was treated as follow: Aliquot No: 2: kept at refrigerator at $-4^{\circ} \mathrm{C}$ for $2 \mathrm{~h}$, Aliquot No: 3: kept at refrigerator at $-4^{\circ} \mathrm{C}$ for $24 \mathrm{~h}$, Aliquot No: 4: kept in the water-bath at $33^{\circ} \mathrm{C}$ for $2 \mathrm{~h}$, Aliquot No: 5: kept in the water-bath at $33{ }^{\circ} \mathrm{C}$ for $24 \mathrm{~h}$.

All the serum aliquots in the refrigerator and in the water-bath were protected from light. Before analysis refrigerated samples were kept for $3 \mathrm{~min}$ at room temperature for freeze thawing. 
Determination of effect of light on serum bilirubin concentration

Determination of effect of sun-light

To determine the effect of sun-light, Aliquot No: 6 from all 34 serum samples were kept near an opened laboratory window, exposing to sun-light for $6 \mathrm{~h}$ at ambient temperature.

Determination of effect of artificial light

To determine the effect of artificial light, Aliquot No 7 from all 34 serum samples were placed under a light source for 24 hat ambient temperature. The distance between the light source and the sample set was $240 \mathrm{~cm}$ ( 8 feet). The Light source was two CFL bulbs, $15 \mathrm{~W}, 220 /$ $240 \mathrm{~V}, 50 / 60 \mathrm{~Hz}$.

Table 1 summarizes that how each serum aliquot was treated to find out the effect of temperature and light on serum bilirubin concentration. All 7 aliquots from each serum sample were treated according to the Table 1

\section{Analysis of serum bilirubin}

\section{Instrumentation and Reagent}

The total and direct serum bilirubin levels of all the serum samples were measured using automated analyzer Mindray BF 300 analyzer, China. The instrument was calibrated for the measurement of serum bilirubin. Two quality control samples were run with the serum samples.

Bio lab bilirubin kit for both total and direct bilirubin measurements RFF 80403 was used to determine the different bilirubin fractions.

\section{Principle of the reaction}

Dimethylsulfoxide (DMSO) method was used to determine the bilirubin concentration. The reaction between bilirubin and diazotized sulfanilic acid yields azobilirubin. Direct bilirubin reacts with diazotized sulfanilicacid in aqueous medium. To enable the assay of total bilirubin it is necessary to break the link between unconjugated bilirubin and albumin, which is done by dimethylsulfoxide (DMSO). The absorbance of azobilirbin is proportional to the bilirubin concentration, which is measured at $550 \mathrm{~nm}$.

\section{Data analysis}

Data analysis was done using software SPSS version 21. The difference between the control group (base-line bilirubin values) and all the other subsequent measurements were analyzed with ANOVA (analysis of variance) with post hoc Dunnet's test based on observed means. The error term is Mean Square (Error) $=.003$. The mean difference is significant at the 0.05 level.

\section{Results}

Analysis of demographic characteristics of the study population

Thirty-four healthy subjects within 1835 years were recruited in the study. Out of 34 healthy subjects, 11 were males and 23 were females.

Base-line serum bilirubin levels in the study population

One set of serum aliquots (aliquot No:1) from all 34 serum samples was analyzed to determine the base-line bilirubin vales in the study population. This was done immediately after the serum separation. Even though apparently healthy individuals were enrolled in the study, 8 subjects out of 34 were hyperbilirubinaemic and their total bilirubin concentration was varied from 1.23 to $2.43 \mathrm{mg} / \mathrm{dL}$ whereas others were $(n=26)$ normobilirubinaemic.

Effect of temperature on serum bilirubin concentration

Effect of temperature $33^{\circ} \mathrm{C}$ after keeping for $2 \mathrm{~h}$ 
Wickrama Rathnage Sureka Damayanthi, Atthanayaka Mudiyanselage Srimali Bandara, Athapaththu Mudiyanselage Buddhika Priyadarshani. How do light and temperature affect laboratory investigations on serum bilirubin?

With regard to serum total, direct and indirect bilirubin, there was no significant difference in between base-line values and at $33{ }^{\circ} \mathrm{C}$ after keeping for $2 \mathrm{~h}$ with light protection.

Effect of temperature $33{ }^{\circ} \mathrm{C}$ after keeping for $24 \mathrm{~h}$

However, there was a significant deference in between base-line values and values obtained after storing at $33{ }^{\circ} \mathrm{C}$ for $24 \mathrm{~h}$ with regard to total and indirect bilirubin values when normobilirubinaemic subjects are concerned. But, there was no significant reduction in direct bilirubin values. When hyperbilirubinaemic subjects are considered, there was a significant reduction in between base-line values and values obtained after storing at $33{ }^{\circ} \mathrm{C}$ for $24 \mathrm{~h}$ with regard to total, direct and indirect bilirubin.

Effect of temperature $-4^{\circ} \mathrm{C}$ after keeping for $2 \mathrm{~h}$

According to statistical analysis, with regard to serum total, direct and indirect bilirubin, there was no any significant difference in between base-line values and at $-4{ }^{\circ} \mathrm{C}$ after keeping for $2 \mathrm{~h}$ with light protection.

Effect of temperature $-4{ }^{\circ} \mathrm{C}$ after keeping for $24 \mathrm{~h}$

Even after $24 \mathrm{~h}$ at $-4{ }^{\circ} \mathrm{C}$, there was no any significant difference in total, direct and indirect bilirubin values compared to base-line values.

Effect of light on serum bilirubin concentration

Effect of sun-light after keeping for $6 \mathbf{h}$

Samples exposed to sun-light for $6 \mathrm{~h}$ showed that there was a significant reduction in total, direct and indirect bilirubin values compared to base-line values in both normobilirubinaemic as well as in hyperbilirubinaemic samples.
This was the highest percentage reduction in bilirubin concentrations that observed during the study.

\section{Effect of artificial light after keeping} for $24 \mathrm{~h}$

According to the statistical analysis, there was a significant reduction in total and indirect bilirubin concentrations in the sample with normobilirubinaemia after keeping under the artificial light source for $24 \mathrm{~h}$ compared to the base-line values. But there was no significant difference in direct bilirubin concentrations. Same observation was notes in the hyperbilirubinaemia samples. In hyperbilirubinaemia samples there was a significant reduction in total and indirect bilirubin values after keeping under the artificial light source for $24 \mathrm{~h}$ compared to the base-line values. But there was no significant difference in direct bilirubin concentrations.

Table 2 summarizes that how temperature and light treatment affect different bilirubin fractions in normobilirubinaemic and hyperbilirubinaemic serum samples. The effect has been given compared to baseline values.

\section{Discussion}

Bilirubin molecule is known to be a photosensitive molecule. When the linear structure of bilirubin molecule is considered it is a highly polar molecule and can be easily execrated. But linear structure of the bilirubin is not the structure which exists in the nature because it has the ability to convert the structure in to chiral, mirror image conformations and it is highly non-polar (Mcdonagh, 1985). To make it soluble, bilirubin molecule is conjugated with two glucuronic acid molecules in the liver. Hence, in the human serum there is 
conjugated bilirubin as well as unconjugated bilirubin which is bound with serum protein albumin (Harvey and Ferrier, 2011; Murray et al., 2003). When analyzing serum bilirubin concentration total, direct (conjugated) and indirect (unconjugated) bilirubin is measured for disease diagnosis purposes.

Our study showed that, with regard to total, direct and indirect bilirubin there is no significant difference in between base-line values and after storing serum samples at $33{ }^{\circ} \mathrm{C}$ for $2 \mathrm{~h}$ with light protection (in both normobilirubinaemic and hyperbilirubinaemic subjects). This finding is supported by the study carried out by Tanner et al., which showed that bilirubin is stable at temperature $15^{\circ} \mathrm{C}$, $25{ }^{\circ} \mathrm{C}$ and $35^{\circ} \mathrm{C}$ up to at least $24 \mathrm{~h}$ but in the whole blood (Tanner et al., 2008). However, in normobilirubinaemic subject's a significant reduction in total and indirect bilirubin was observed after storing serum samples at $33{ }^{\circ} \mathrm{C}$ for $24 \mathrm{~h}$ with light protection. But there was no significant reduction in direct bilirubin concentrations. But in hyperbilirubinaemic subjects in addition to total and direct bilirubin there was a significant reduction in direct bilirubin concentration as well. Contrast to our finding Tanner et al., showed that bilirubin is stable at $35^{\circ} \mathrm{C}$ up to at least $24 \mathrm{~h}$ prior to centrifugation and in this case, they had been used whole blood instead of serum (Tanner et al., 2008). Sofronescu et al., showed that there is no statistically significant difference in direct bilirubin values after storing plasma samples at $3{ }^{\circ} \mathrm{C}$ and $22{ }^{\circ} \mathrm{C}$ for $2,4,8$, $24 \mathrm{~h}$ (Sofronescu et al., 2012). However, it is difficult to compare these vales with our results as the temperature used was different in two studies.
According to the statistical analysis, our study showed that there is no significant reduction in bilirubin after storing serum samples at $-4{ }^{\circ} \mathrm{C}$ with light protection for $2 \mathrm{~h}$ and $24 \mathrm{~h}$. This finding is supported by the findings of Morishita et al., which showed that bilirubin is stable at $-20{ }^{\circ} \mathrm{C} / 4{ }^{\circ} \mathrm{C}$ for 7 days with or without light exposure (Morishita et al., 1994). However, in that case temperature used was higher than the temperature used by us ie., $4{ }^{\circ} \mathrm{C}$. Further, in present study there was a little change in ratio of direct bilirubin to total bilirubin at $-4{ }^{\circ} \mathrm{C}$ which was observed in both normobilirubinaemic and hyperbilirubinaemic samples. Morishita et al., noted the same observation but at $20{ }^{\circ} \mathrm{C} / 4{ }^{\circ} \mathrm{C}$. However, $\mathrm{t}$ gradually lowering of the ratio at $25^{\circ} \mathrm{C}$ over time could be seen (Morishit et al., 1994).

Ihara et al., conducted a study to determine the effects of thermo-stability on bilirubin sub-fractions of serum bilirubin. One unconjugated and three conjugated hyperbilirubinaemic serum samples had been filled with nitrogen and incubated in-vitro at $4{ }^{\circ} \mathrm{C}, 25{ }^{\circ} \mathrm{C}, 37{ }^{\circ} \mathrm{C}$ for $6 \mathrm{~h}$ in the dark. Authors had observed that there is no difference in total bilirubin concentration in both conjugated and unconjugated hyperbilirubinaemic serum samples at $4{ }^{\circ} \mathrm{C}, 25^{\circ} \mathrm{C}$ and $37^{\circ} \mathrm{C}$ up to 6 h. A decrease of direct bilirubin concentrations with the incubation time and temperature could be observed. Authors reported that direct bilirubin is stable at $4{ }^{\circ} \mathrm{C}$ for $6 \mathrm{~h}$, at $25^{\circ} \mathrm{C}$ and at 37 ${ }^{\circ} \mathrm{C}$ for 1.5 hours. Serum total, direct, and indirect concentrations remained unchanged in unconjugated hyperbilirubinaemic serum samples at 4 ${ }^{\circ} \mathrm{C}, 25{ }^{\circ} \mathrm{C}, 37{ }^{\circ} \mathrm{C}$ up to $6 \mathrm{~h}$. However, authors had concluded that thermo- 
Wickrama Rathnage Sureka Damayanthi, Atthanayaka Mudiyanselage Srimali Bandara, Athapaththu Mudiyanselage Buddhika Priyadarshani. How do light and temperature affect laboratory investigations on serum bilirubin?

stability of the bilirubin sub-fractions are in the order of delta bilirubin, unconjugated bilirubin, mono-conjugated bilirubin, and di-conjugated bilirubin (Ihara et al., 2010).

However, reason for the changes in bilirubin level and structure with temperature for various time durations has not been addressed. The structure of the bilirubin may be changed after exposing serum samples at $33{ }^{\circ} \mathrm{C}$ for $24 \mathrm{~h}$ due to the changes of bonds in bilirubin molecules. Newly formed structures may not be reacted with diazotized sulfanilic acid to form azobilirubin (red color) at pH 1.4 in DMSO method which is the method used in present study. Because of that, concentration of the azobilirubin formed from the reaction may be reduced. Therefore, intensity of the color product can also be reduced. As the intensity of the color produced is directly proportional to the concentration of the bilirubin, the amount of bilirubin may be reduced. Rate of structural changes in bilirubin molecules/ breakdown of bilirubin may be increased with temperature and time duration. Therefore, fewer changes in bilirubin values could be observed at $-4{ }^{\circ} \mathrm{C}$ after $2 \mathrm{~h}$ compared to $24 \mathrm{~h}$. Hence, serum samples can be stored at $-4{ }^{\circ} \mathrm{C}$ for $24 \mathrm{~h}$ and at $33{ }^{\circ} \mathrm{C}$ for $2 \mathrm{~h}$ with light protection if there is any delay in analysis of the serum samples to be analyzed for bilirubin.

To determine the effect of sun-light, aliquoted serum sample set was kept near the window in a sunny day for $6 \mathrm{~h}$. All the samples were kept in the way that they get sun-light equally. There was a significant reduction in total, direct and indirect bilirubin values when compared to baseline values. The lowest reduction could be seen in direct bilirubin fraction. In comparison all the treatment methods, the highest reduction in total, direct and indirect bilirubin concentrations were observed in the samples which exposed to sun-light during the present study. A previous study had been conducted to determine the effect of sun-light by using prepared bilirubin solutions and the results revealed that significant reduction in bilirubin concentration. These results support our findings. But in that case bilirubin solutions had been used instead of serum samples. An in-vivo study carried out by using jaundiced infants indicated that filtered sun-light is less effective when compared to conventional (Rehak et al., 2008). But, another study showed that filtered sun-light is an effective treatment in neonatal jaundice and it can be used where conventional phototherapy is not available (Leung et al., 1992).

The reason for the reduction of bilirubin levels after exposing to sun-light is the photo-irradiation of bilirubin molecules. When bilirubin molecule is exposed to sunlight, photo-isomerization of native bilirubin molecule occurs, resulting formation of conformational isomers and structural isomers.In the structural photo-isomerization, bilirubin molecule twisted irreversibly resulting different shape known as Z-lumirubin. This result in open up of hydrogen bonds from a one end of the native bilirubin molecule causing exposure of polar groups in the molecule (Mcdonagh, 1985; Goncharova et al., 2015).

In the conformational isomerization bilirubin molecule undergoes $\mathrm{Z}$ E reversible isomerization. This occurs at the double bonds in carbon molecules of $\mathrm{C}$ 4 and $\mathrm{C}-15$. The reaction can occur in both carbon molecules or in one carbon molecule. Therefore, there can be three 
isomeric products of bilirubin molecule ie., $4 \mathrm{Z}, 15 \mathrm{E}-$, $4 \mathrm{E}, 15 \mathrm{Z}-$ and $4 \mathrm{E}, 15 \mathrm{E}$ bilirubin (Mcdonagh, 1985; Amin and Ahlfors, 2008; Mreihil et al., 2010). But when this conformational isomerization occurs in-vitro the most predominant product is $4 \mathrm{Z}, 15 \mathrm{E}$ - bilirubin (Mcdonagh, 1985). Due to this photo-irradiation, native bilirubin molecule converts in to different isomeric products. Hence, the reaction of native bilirubin molecules with the reagent molecules affects, the formation of azobilirubin is decreased. This is resulted in low bilirubin concentration in the samples which exposed to sun-light compared to base-line values. The unconjugated bilirubin more prone to photo-irradiation than conjugated bilirubin (Mcdonagh, 1985), hence the reduction of unconjugated fraction is more compared to conjugated fraction of bilirubin.

The effect of artificial light was studied by exposing serum samples to two CFL bulbs. The samples with high and normal bilirubin concentrations showed significant reduction in total and indirect fractions after exposed to the light source for $24 \mathrm{~h}$. Sofronescu et al., had found that significant reduction in total, direct and indirect bilirubin with normal bilirubin concentrations after exposing to artificial light for $24 \mathrm{~h}$. Further, there is a decrease in both total and direct bilirubin in the samples where elevated bilirubin concentrations after exposing to artificial light for $48 \mathrm{~h}$. However, Phili ps bulb had been used in the study and whole blood samples had been exposed to the light source (Sofronescu et al., 2012). Another study showed that significant reduction in bilirubin concentrations after exposing serum samples to fluorescent light (intensity of 1,100 lumen/m?) 6 feet below a light fixture for $2 \mathrm{~h}$. But in this study authors had concluded that precautions to protect the bilirubin from the light should be taken while handling specimens with normal bilirubin concentrations rather than specimens with high bilirubin concentrations (Rehak et al., 2008). A study conducted using serum samples from jaundiced newborn infants, found that a significant decrease in the bilirubin values at $6 \mathrm{~h}$ after samples were exposed to white fluorescent light (Leung et al., 1992). Another in-vivo study conducted using jaundiced infants indicated that LED light and turquoise light had similar effect in reducing bilirubin after $24 \mathrm{~h}$ exposure period (Ebbesen et al., 2016).

The reason for the reduction in bilirubin after exposing to artificial light is same as with that of the reason explained under the effect of sun-light. The most effective light source to reduce the bilirubin by photo-irradiation is blue fluorescent light (Salih, 2001; Slusher et al., 2015). The sun-light covers a large portion of the light spectrum including the bilirubin-absorbing range ie., blue light (Rashid et al., 2000). But, when artificial light source is used it doesn't include the same spectrum as sun-light. It could be the reason for the higher reduction in bilirubin after exposed to serum samples to sun-light compared to artificial light.

Serum bilirubin is stable at $-4{ }^{\circ} \mathrm{C}$ up to $24 \mathrm{~h}$ and at $33{ }^{\circ} \mathrm{C}$ up to $2 \mathrm{~h}$ with light protection. Serum bilirubin is drastically reduced when expose to sun-light for $6 \mathrm{~h}$. When serum samples containing bilirubin are exposed to two CFL bulbs, with the distance between light source and serum samples $240 \mathrm{~cm}$ for $24 \mathrm{~h}$, indirect and total bilirubin concentrations are 
Wickrama Rathnage Sureka Damayanthi, Atthanayaka Mudiyanselage Srimali Bandara, Athapaththu Mudiyanselage Buddhika Priyadarshani. How do light and temperature affect laboratory investigations on serum bilirubin?

significantly reduced but direct bilirubin fraction does not change significantly up to $24 \mathrm{~h}$.

\section{Acknowledgement}

We would like to express our sincere thanks to the subjects who participated in the study. We owe special thanks to Mr. P. Dias for his valuable support for statistical data analysis. Our extreme gratitude goes to Mr. B.B.I.N Priyankara and Mr. H.P Asanka for their kind cooperation given during this study.

\section{References}

1. Amin, S.B., Ahlfors, C. (2008) Effect of storage and freezing on unbound bilirubin measurement. Clin. Chim. Acta. 396: 56-7.

2. Ebbesen, F., Vandborg, P.K., Madsen, P.H., Trydal, T., Jakobsen, L.H., Vreman, H.J. (2016). Effect of phototherapy with turquoise-versus blue LED light of equal irradiance in jaundiced neonates. Pediatr. Res. 79: 308-12.

3. Goncharova, I., Ja?prov?, J., V?tek, L., Urbanov?, M. (2015). Photo-isomerization and oxidation of bilirubin in mammals is dependent on albumin binding. Anal. Biochem. 490: 34-45.

4.Harvey, R.A., Ferrier, D,R, editors (2011): Lippincott's Illustrated Reviews: Biochemistry.Lippincott Williams \& Wilkins.

5. Ihara, H., Kakinoki, T., Morita, Y., Matsumoto, N., Shino, Y. (2010). Effects of thermostability of bilirubin subfractions on serum bilirubin measurement. J. Anal. Bio-Sci., 33: 223-6

6. Leung, C.I., Soong, W.J., Chen, S.J. (1992). Effect of light on total micro-bilirubin values in-vitro. Zhonghua.Y.i XueZaZhi.(Taipei).50: 41-5.

7. Mcdonagh, A.F (1985). Light effects on transport and excretion of bilirubin in newborns. Ann. N. Y. Acad. Sci., 453: 65-72.

8. Morishita, Y., Nakane, K., Fukatsu, T. (1994). Stability of serum bilirubin with or without lighting at various temperatures. Japanese. J. Clin. Chem., 23: 170-77.

9. Mreihil, K., McDonagh, A.F., Nakstad, B., Hansen, T.W.R. (2010). Early isomerization of bilirubin in phototherapy of neonatal jaundice. Pediatr. Res. 67: 656-9.

10. Murray, R.K., Granner, D.K., Mayes, P.A., Rodwel, V.W. editors (2003): Harper's Illustrated BiochemistryLange Medical Books/McGraw-Hill.

11. Rashid, H., Ali, M.K., Tayyab, S. (2000). Effect of $\mathrm{pH}$ and temperature on the binding of bilirubin to human erythrocyte membranes. J. Biosci. 25: 157-61.

12. Rehak, N.N., Cecco, S.A., Hortin, G.L. (2008). Photolysis of bilirubin in serum specimens exposed to room lighting. Clin. Chim. Acta., 387: 181-3.

13. Salih, F.M. (2001) Can sunlight replace phototherapy units in the treatment of neonatal jaundice? An in-vitro study. Photodermatol. Photoimmunol. Photomed. 17: 272-7.

14. Saththasivam, P., Voralu, K., Ramli, N., Mustapha, M.R., Omar, J., Van Rostenberghe, H. (2010). The effect of delayed transportation of blood samples on serum bilirubin values in neonates. The. Malays. J. Med. Sci., 17: 27-31.

15. Slusher, T.M., Olusanya, B.O., Vreman, H.J., Brearley, A.M., Vaucher, Y.E., Lund, T.C., Wong, R.J., Emokpae, A.A., Stevenson, D.K. (2015). A Randomized trial of phototherapy with filtered sunlight in African neonates. N. Engl. J. Med. 373: 1115-24.

16. Sofronescu, A.G., Loebs, T., Zhu, Y. (2012). Effects of temperature and light on the stability of bilirubin in plasma samples. Clin. Chim. Acta. 413: 463-6.

17. Tanne, M., Kent, N., Smith, B., Fletcher, S., Lewer, M. (2008). Stability of common biochemical analytes in serum gel tubes subjected to various storage temperatures and times pre-centrifugation. Ann. Clin. Biochem. 45: 375-9

18. Westwood, A. (1991): The analysis of bilirubin in serum. Ann. Clin. Biochem., 28: 119-30 
Journal of research in health science. 2018; 1 (2): 4-13.

Table 1: Temperature and light exposure of serum aliquots

\begin{tabular}{ll}
\hline Aliquot No: & Temperature/heat exposure \\
\hline Aliquot No: 01 & $\begin{array}{l}\text { No temperature/heat exposure } \\
\text { Kept in refrigerator at }-4{ }^{\circ} \mathrm{C} \text { for } 2 \mathrm{~h} \\
\text { Aliquot No: } 02\end{array}$ \\
Aliquot No: 03 & $\begin{array}{l}\text { Kept in refrigerator at }-4{ }^{\circ} \mathrm{C} \text { for } 24 \mathrm{~h} \\
\text { No light exposure } \\
\text { Kept in water-bath at } 33{ }^{\circ} \mathrm{C} \text { for } 2 \mathrm{~h} \\
\text { No light exposure } \\
\text { Kept in water-bath at } 33{ }^{\circ} \mathrm{C} \text { for } 24 \mathrm{~h} \\
\text { No light exposure } \\
\text { Exposed to sun-light for } 6 \mathrm{~h}\end{array}$ \\
Aliquot No: 05 & $\begin{array}{l}\text { At ambient temperature } \\
\text { Exposed to artificial light for } 24 \mathrm{~h} \\
\text { At ambient temperature }\end{array}$ \\
Aliquot No: 06 & \\
Aliquot No: 07 & \\
\hline
\end{tabular}

Number of serum samples $=34$

The artificial light source: two CFL bulbs, $15 \mathrm{~W}, 220 / 240 \mathrm{~V}, 50 / 60 \mathrm{~Hz}$

Table 2: The effect of temperature/light on serum bilirubin concentration

\begin{tabular}{|c|c|c|c|c|}
\hline \multirow{2}{*}{$\begin{array}{l}\text { Temperature/ } \\
\text { light treatment }\end{array}$} & \multirow{2}{*}{$\begin{array}{l}\text { Bilirubin category } \\
\text { of the subjects }\end{array}$} & \multicolumn{3}{|c|}{ Bilirubin concentration } \\
\hline & & $\begin{array}{l}\text { Total } \\
\text { bilirubin }\end{array}$ & $\begin{array}{l}\text { Direct } \\
\text { bilirubin }\end{array}$ & $\begin{array}{l}\text { Indirect } \\
\text { bilirubin }\end{array}$ \\
\hline $33^{\circ} \mathrm{C}$ for $2 \mathrm{~h}$ & $\begin{array}{l}\text { Normobilirubinaemic } \\
\text { samples } \\
\text { Hyperbilirubinaemic } \\
\text { samples }\end{array}$ & $\begin{array}{l}\text { No significant } \\
\text { reduction } \\
\text { No significant } \\
\text { reduction }\end{array}$ & $\begin{array}{l}\text { No significant } \\
\text { reduction } \\
\text { No significant } \\
\text { reduction }\end{array}$ & $\begin{array}{l}\text { No significant } \\
\text { reduction } \\
\text { No significant } \\
\text { reduction }\end{array}$ \\
\hline $33^{\circ} \mathrm{C}$ for $24 \mathrm{~h}$ & $\begin{array}{l}\text { Normobilirubinaemic } \\
\text { samples } \\
\text { Hyperbilirubinaemic } \\
\text { samples }\end{array}$ & $\begin{array}{l}\text { Significant } \\
\text { reduction } \\
\text { Significant } \\
\text { reduction }\end{array}$ & $\begin{array}{l}\text { No significant } \\
\text { reduction } \\
\text { Significant } \\
\text { reduction }\end{array}$ & $\begin{array}{l}\text { Significant } \\
\text { reduction } \\
\text { Significant } \\
\text { reduction }\end{array}$ \\
\hline$-4{ }^{\circ} \mathrm{C}$ for $2 \mathrm{~h}$ & $\begin{array}{l}\text { Normobilirubinaemic } \\
\text { samples } \\
\text { Hyperbilirubinaemic } \\
\text { samples }\end{array}$ & $\begin{array}{l}\text { No significant } \\
\text { reduction } \\
\text { No significant } \\
\text { reduction }\end{array}$ & $\begin{array}{l}\text { No significant } \\
\text { reduction } \\
\text { No significant } \\
\text { reduction }\end{array}$ & $\begin{array}{l}\text { No significant } \\
\text { reduction } \\
\text { No significant } \\
\text { reduction }\end{array}$ \\
\hline$-4^{\circ} \mathrm{C}$ for $24 \mathrm{~h}$ & $\begin{array}{l}\text { Normobilirubinaemic } \\
\text { samples } \\
\text { Hyperbilirubinaemic } \\
\text { samples }\end{array}$ & $\begin{array}{l}\text { No significant } \\
\text { reduction } \\
\text { No significant } \\
\text { reduction }\end{array}$ & $\begin{array}{l}\text { No significant } \\
\text { reduction } \\
\text { No significant } \\
\text { reduction }\end{array}$ & $\begin{array}{l}\text { No significant } \\
\text { reduction } \\
\text { No significant } \\
\text { reduction }\end{array}$ \\
\hline $\begin{array}{l}\text { Exposed to sun- } \\
\text { light for } 6 \mathrm{~h}\end{array}$ & $\begin{array}{l}\text { Normobilirubinaemic } \\
\text { samples } \\
\text { Hyperbilirubinaemic } \\
\text { samples }\end{array}$ & $\begin{array}{l}\text { Significant } \\
\text { reduction } \\
\text { Significant } \\
\text { reduction }\end{array}$ & $\begin{array}{l}\text { Significant } \\
\text { reduction } \\
\text { Significant } \\
\text { reduction }\end{array}$ & $\begin{array}{l}\text { Significant } \\
\text { reduction } \\
\text { Significant } \\
\text { reduction }\end{array}$ \\
\hline $\begin{array}{l}\text { Exposed to } \\
\text { artificial light for } \\
24 \mathrm{~h}\end{array}$ & $\begin{array}{l}\text { Normobilirubinaemic } \\
\text { samples } \\
\text { Hyperbilirubinaemic } \\
\text { samples }\end{array}$ & $\begin{array}{l}\text { Significant } \\
\text { reduction } \\
\text { Significant } \\
\text { reduction }\end{array}$ & $\begin{array}{l}\text { No significant } \\
\text { reduction } \\
\text { No significant } \\
\text { reduction }\end{array}$ & $\begin{array}{l}\text { Significant } \\
\text { reduction } \\
\text { Significant } \\
\text { reduction }\end{array}$ \\
\hline
\end{tabular}

Number of serum samples $=34$

The difference between the control group (base-line bilirubin values) and all the other subsequent measurements were analyzed with ANOVA (analysis of variance) with post hoc Dunnet's test based on observed means

The error term is Mean Square (Error) $=.003$.

The mean difference is significant at the 0.05 level 